\title{
Middle Jurassic black shales (Skrzypny Shale Formation) - palaeoenvironmental significance of one of the oldest deposits of the Pieniny Klippen Belt
}

\author{
Środkowojurajskie czarne łupki (formacja łupków ze Skrzypnego) - znaczenie \\ paleośrodowiskowe jednych z najstarszych osadów pienińskiego pasa skałkowego
}

\author{
Katarzyna Górniak' ${ }^{1}$ Krzysztof Bahranowski', Adam Gawel', \\ Leszek Marynowski ${ }^{2}$ \& Tadeusz Szydlak ${ }^{1}$ \\ ${ }^{1}$ AGH University of Science and Technology, Department of Mineralogy, Petrography and Geochemistry, \\ 30-059 Kraków, al. Mickiewicza 30, Poland; \\ e-mail:gorniak@agh.edu.pl \\ ${ }^{2}$ University of Silesia, Faculty of Earth Sciences, 41-200 Sosnowiec, ul. Będzińska 60, Poland \\ e-mail:marynows@wnoz.us.edu.pl
}
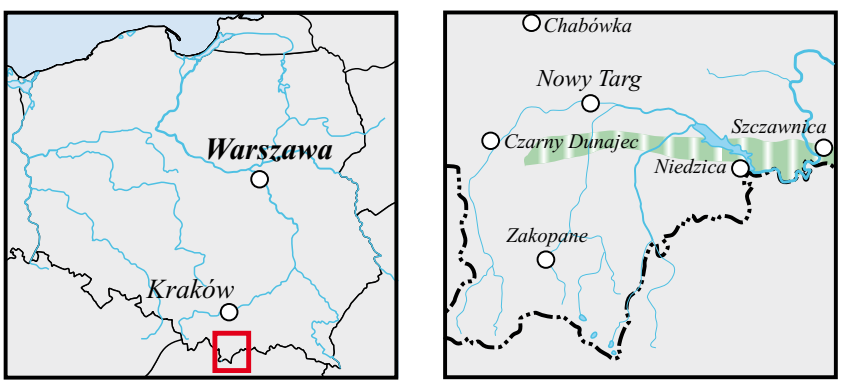

Abstract: This paper deals with a fragment of geological history of Middle Jurassic black spherosideritic shales outcropping in upper part of the Homole Gorge (Skrzypny Shale Formation, Niedzica succession). These important deposits belong to the Flackenmergel facies, widespread in oceanic Tethyan deposits. This formation represents one of the oldest rocks of the Pieniny Klippen Belt. Dark colour of these rocks (total organic carbon content in them amounts to about $1 \mathrm{wt} . \%$ ) and the occurrence of siderite concretions indicate reducing conditions of their origin but oxidizing environment of waters above them in sedimentary basin. Oxic conditions of organic matter sedimentation are confirmed by the elevated values of pristine to phytane ratio. Moreover the results based on n-alkanes indicate mixed terrestrial/marine origin of organic matter with prevalence of the last one These information are slightly obliterated because of advanced thermal maturity of organic matter caused by postsedimentation processes. Microstructural features of deposits of the Skrzypny Shale Formation and the composition of clay minerals occurring in them indicate late diagenetic conditions. In SEM images we observe one-directional orientation of clay minerals and rotation of mica flakes, often chloritized. Clay minerals are represented by high-illitic illite/smectite, micas, post-biotitic chlorite and subordinately kaolinite. As follows from authors studies, these macroscopically nearly "mute" clay rocks, little interesting in outcrops, particularly when they occur in such attractive geological objects as the Homole Gorge, can be the source of important information concerning the history of sedimentation basins.

Key words: Pieniny Klippen Belt, middle Jurassic, black shales, mikrostructure, clay minerals

Treść: Praca przedstawia fragment historii geologicznej środkowojurajskich czarnych tupków sferosyderytowych ukazujacych się $w$ niewielkim odsłonięciu $w$ górnej części wawozu Homole (formacja tupków ze Skrzypnego, sukcesja niedzicka). Te ważne utwory należq do facji Fleckenmergiel szeroko rozpowszechnionej $w$ oceanie Tetydy. Formacja tupków ze Skrzypnego reprezentuje jedne z najstarszych skat pienińskiego pasa skatkowego. Ciemna barwa badanych skat (zawartość całkowitego wegla organicznego około 1\% wag.) oraz występowanie $w$ nich konkrecji syderytowych, wskazuja na warunki redukcyjne panujace w osadzie, natomiast na obecność natlenionych wód nad osadem w'środowisku ich sedymentacji. Sedymentacje substancji organicznej $w$ warunkach raczej utleniajacych potwierdzaja badania zwiqzków organicznych, tj. wysokie wartości stosunku pristan/fitan. Wyniki tych badań wskazuja ponadto na mieszane, ladowo/morskie pochodzenie substancji organicznej z przewaga ostatniej z wymienionych. Informacje te sq nieco zatarte z powodu dużej dojrzatości termicznej substancji organicznej spowodowanej procesami postsedymentacyjnymi. Cechy mikrostrukturalne utworów formacji tupków ze Skrzyponego oraz sklad wystęujacych $w$ nich minerałów ilastych wskazuja na warunki odpowiadajace póżnej diagenezie. Wobrazach elektronomikroskopowych (SEM) widoczna jest bowiem jednokierunkowa orientacja minerałów ilastych i rotacja blaszek mik, czessto schlorytyzowanych. W sktadzie minerałów ilastych występuje zaś wysokoillitowy illit/ smektyt, miki, pobiotytowy chloryt i podrzędnie kaolinit.

$Z$ przeprowadzonych badań wynika, że makroskopowo niemal „nieme" skaty ilaste, niepozorne wygladajace w odstonięciu, szczególnie jeśli wystęuja obok atrakcyjnych obiektów geologicznych jak to ma miejsce $w$ wawozie Homole, sq źródtem ważnych informacji dotyczacych historii basenów sedymentacyjnych. Warto więc zwrócić na nie uwagę.

Słowa kluczowe: Pieniński Pas Skatkowy, jura środkowa, czarne tupki, mikrostruktura, mineraty ilaste

\section{Introduction}

Early Jurassic dark marly facies (of Fleckenmergel type) are particularly interesting for researchers since in them there are recorded the initial stages of evolution of the Pieniny basin (Birkenmajer, 1986, Krobicki \& Golonka 2008a and the references in these papers). In Polish part of the Pieniny Klippen Belt one of the oldest rocks belonging to this facies are dark sphaerosideritic shale with Bositra bivalve (Skrzypny Shale Formation) of Late Aalenian-Early Bajocian age (Krobicki 
\& Golonka, 2008a, Fig. 7). This formation is described as a series of clay rocks of black and black-greenish colour, containing sphaerosideritic concretions and sometimes ammonites. The thickness of this formation amounts to approximately $5 \mathrm{~m}$. These interesting deposits are outcropping in upper part of the Homole Gorge, at the pass below Czajakowa Skała Klippe (Krobicki \& Golonka, 2008a, Fig. 12D).

\section{Outcrop at the pass below Czajakowa Skała Klippe}

The Skrzypny Shale Formation outcropping here belongs to the Niedzica succession. The deposits of this succession occur in the form of a slice contacting tectonically with underlying rocks. This slice represents an overturned fold, strongly tectonically folded and forming the Czajakowa Skała Klippe. The Skrzypny Shale Formation occurs in the bottom of the Niedzica succession rock complex. A fragment of Czajakowa Skała fold was displaced on a bed of these shales, representing sliding plane, and actually they occur in a landslide in upper part of the Homole Gorge (Krobicki \& Golonka, 2008a, Fig. 12D). In this small outcrop the shales in question represent fine slaty, dark gray-olive shales containing mica flakes up to $0.5 \mathrm{~mm}$ in size and brown sideritic concretions. These shales are soft, poorly calcareous, containing no sand fraction. The size of sphaerosiderites does not exceed a dozen $\mathrm{cm}$. They are hard, containing fractures filled with calcite. These carbonate concretions from other occurrence of these shales of the Niedzica succession in Kapuśnica near Niedzica castle were examined in detail by W. Narębski (Birkenmajer \& Narębski, 1957). They were found to contain, apart from sideroplesitic (Mg-sideritic) component, significant admixture of calcite, indicating their deposition in rather deep-water and more offshore marine environment than these shales of the Czorsztyn and Branisko successions. The geochemical character of concretions and shales containing them clearly suggests their early diagenetic origin under conditions of moderately reducing sideritic geochemical facies (Birkenmajer \& Narębski, 1957). This conclusion is confirmed by their loaf-shaped forms (Seilacher, 2001).

Dark colour of sediments initiating sedimentation in the Pieniny basin suggests their deposition under oxygen-deficient conditions enabling preservation of organic matter. Such conditions are characteristic of a source rocks for oil and gas deposits. In Demaison and Moore (1980) opinion, oxygendeficient environment is characterized by the content of less than $0.5 \mathrm{ml}$ oxygen in one litre of water. Such conditions are formed when the request for oxygen in water is higher than its supply. This request depends on the productivity of surface waters and the supply of oxygen to sediments on the circulation of currents. It is considered that oxygen-deficient conditions were particularly common in Upper Jurassic and Lower Cretaceous period because of global worming of climate and an increase of water level in the oceans. The source rocks of the largest known oil and gas deposits are of this age. Moreover, anoxic conditions can be formed but locally. By analogy to actual oceanic environment (continental slope zone of the Indian Ocean) it is considered that oxygen-deficient sediments are accumulating in the areas, where currents transporting oxygen-deficient waters are entering the continental slope. This model corresponds to the conditions dominating in Middle Jurassic Pieniny basin. Dark marly facies sediments of this age appear in rocks of the Niedzica succession deposited on continental slope and in those of the Czorsztyn succession accumulated on the slope of Czorsztyn ridge. As already informed, the former are one of the oldest deposits forming the fold of the Czajakowa Skała Klippe and are observed in uppermost part of the Homole Gorge. The dark shales of the Czorsztyn succession are exposed in the Krupianka stream (Krobicki \& Golonka, 2008a, Fig. 14A, and references in this paper). Bathymetric conditions of formation of sediments of the Fleckenmergel facies, estimated by Tyszka (2001) on the ground of microfossil studies, correspond to the slope zone.

The series of dark clayey rocks accumulating in oxygendeficient environments are usually but apparently monotonous. Complex sedimentologic, palaeontologic and geochemical studies of the Lower Jurassic sediments in Yorkshire, United Kingdom, allowed to distinguish three facies occurring in the basins dominated by generally oxygen-deficient waters. They have resulted in distinguishing normal, restricted and bituminous shales (Morris, 1979). This facial variability is caused by cyclic change of position of the boundary between oxygenated and oxygen-deficient zones in the water column above the sediment. Lithological features of sediments of the Skrzypny Shale Formation of the Niedzica succession outcropping at the pass below Czajakowa Skała Klippe represent the normal shales facies. This conclusion results from the comparison of their properties with those of sediments reported by Morris (1979) for individual facies distinguished. They were formed under conditions when the boundary of oxidizing and reducing conditions was situated within the sediment and oxidized water above the latter. Such environment is favour the development of epifauna and infauna and its accumulation in the sediment (Fig.1). On the other side, in such geochemical facies siderite-bearing concretions can be formed (Birkenmajer \& Narębski, 1957; Potter et al., 2005).

The sediments of the Skrzypny shale formation contain about $1 \mathrm{wt} . \%$ of total organic carbon (TOC) and trace amounts of sulphur. Taking into account weathering of the investigated material, not altered TOC content seems to be higher, which indicate oxygene depletion during deposition or early diagenesis. Increased content of calcite in them indicates rather high

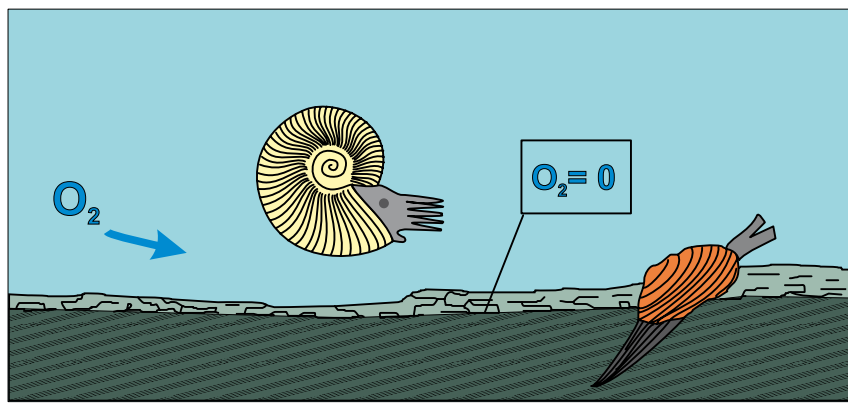

Fig. 1. Presentation of sedimentary conditions of deposits of the Skrzypny Shale Formation based on lithologic and biomarker data - Ilustracja warunków sedymentacji utworów formacji łupków ze Skrzypnego w oparciu o badania cech litologicznych i biomarkerów 


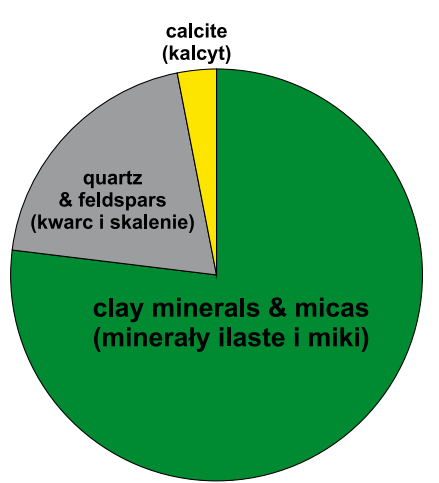

Fig. 2. Semi-quantitative mineral composition of rocks of the Skrzypny Shale Formation from the outcrop at the pass below Czajakowa Skała Klippe (Niedzica succession) based on standard X-ray data $•$ Półilościowy skład mineralny utworów formacji łupków ze Skrzypnego w z odsłonięcia na przełęczy pod Czajakową Skałą (sukcesja niedzicka) określony w oparciu o standardowe badania rentgenogarficzne

$\mathrm{pH}$ of pore waters in this sediments (Birkenmajer \& Narębski 1957). Biomarkers are the indices of redox conditions in sedimentation environment of rocks enriched in organic matter. They represent "molecular fossils" i.e. fragments of organic matter which preserved the internal structure of initial biomolecules. Two isoprenoids: pristine (Pr) and phytane $(\mathrm{Ph})$ were used to determination of water column conditions during Skrzypny shales sedimentation. Elevated $\mathrm{Pr} / \mathrm{Ph}$ ratio amounts to 1.8 suggest rather oxic conditions, but this data should be treated as preliminary. Taking into account relatively high TOC content and rather oxic conditions of the organic matter sedimentation, all this suggest that suboxic to anoxic conditions took place during early stage of diagenesis (Fig. 1). Unfortunately, due to relatively high thermal maturity of the samples and their partial weathering such biomarkers as terpenoids and steroids were not found. The prevalence of short-chain $n$ alkenes, with maximum at $n$-C16 indicates rather marine character of organic matter. However, in the range of long-chain $\mathrm{n}$-alkanes we observe slight prevalence of odd carbon chain $n$-alkanes ( $n$-C27, n-C29, n-C31) what, in turn, indicates a terrestrial component of organic matter. Consequently, these data indicate a mixed terrestrial/marine character of organic matter with distinct prevalence of the marine one.

Because of complicated geological history of the Pieniny Klippen Belt, not only organic matter but also primary features of the Skrzypne Shale Formation could be significantly changed by diagenetic processes and tectonic deformations. The rocks of the Skrzypny Shale Formation of the Niedzica succession, outcropping at the pass below the Czajakowa Skała Klippe are composed mainly of clay minerals and micas (about 77 wt.\%). Clay minerals are represented by high-illitic illite/smectite, illite, chlorite and kaolinite. Moreover, these shales contain quartz (about $20 \mathrm{wt} . \%$ ), trace amounts of feldspars and calcite (about 3 wt.\%) (Fig. 2).

Compaction process resulted in one-directional orientation of flakes of clay minerals (illite/smectite, illite) surrounding fine quartz grains and rare feldspars and bioclasts (Fig. 3). Quartz and feldspar grains (Fig. 4) are very fine, up to a dozen micrometers in size. Bioclasts are strongly destroyed, showing numerous dissolution caverns (Fig. 3). Large, often

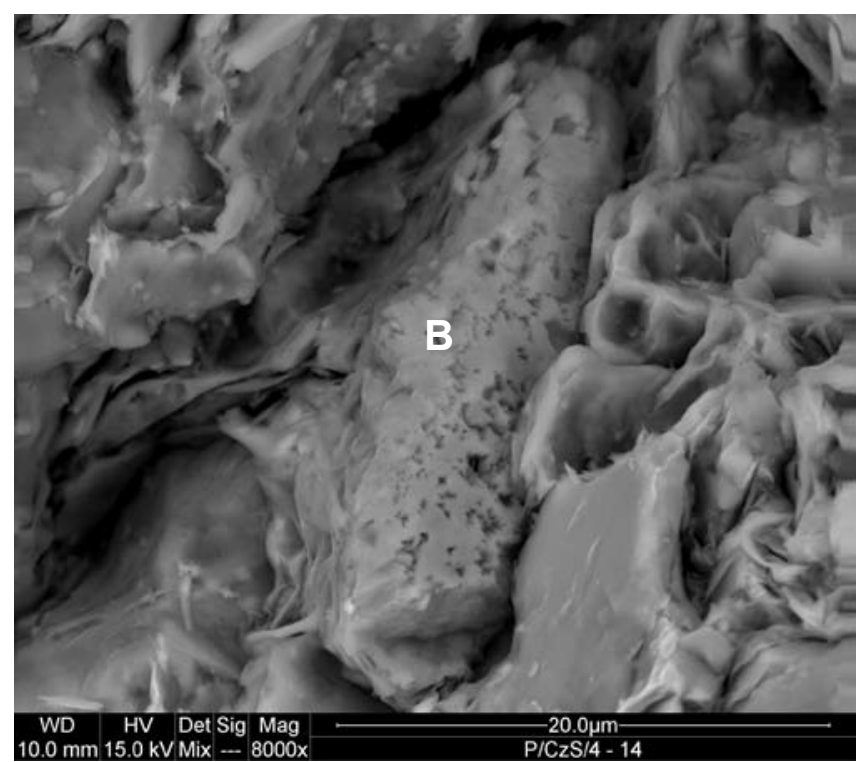

Fig. 3. Bioclasts (B) showing dissolution caverns surrounded by flakes of clay minerals $(\mathrm{SEM} / \mathrm{EDX}) \cdot$ Bioklast $\mathrm{z}$ kawernami z rozpuszczania otoczony przez blaszki minerałów ilastych. (SEM/EDX)

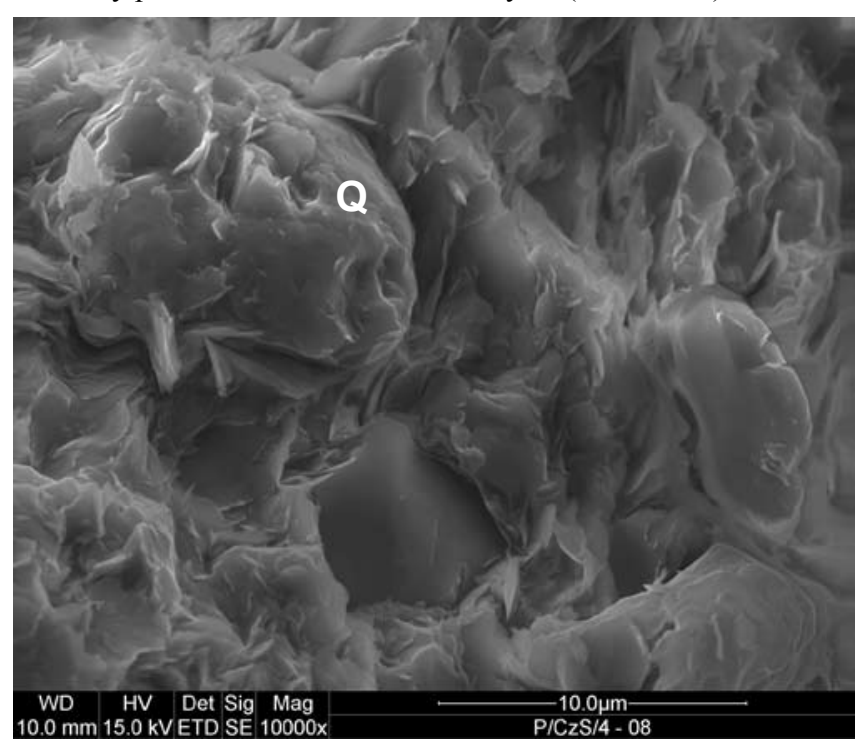

Fig. 4. One-directional orientation of flakes of clay minerals bent on a quartz grain $(\mathrm{Q})$ due to compaction (SEM/EDX) • Jednokierunkowa orientacja blaszek minerałów ilastych ugiętych na ziarnie kwarcu wyniku kompakcji widoczna w badaniach elektronomikroskopowych świeżego przełamu próbki. (SEM/EDX)

strongly chlorotized, mica flakes and kaolinite plates up to a dozen or even several ten micrometers in size (Fig. 5), exhibit rotation by 30 to $90^{\circ}$ relative to one-directional orientation of fine flakes of clay minerals (Fig. 6). According to Weaver (1989) criteria, the above described microstructure, clay mineral composition and the state of preservation of organic matter indicate that the rocks studied were subjected to processes characteristic of late stage of diagenesis. The Skrzypny shales in this outcrop were till now not yet studied in detail. Their geologic history can be reconstructed on the ground of X-ray, geochemical and electron microscope studies using SEM/EDX technique.

As follows from the obtained results, the deposition of sediments of the Skrzypny Shale Formation of the Niedzica succession took place under conditions of oxidized waters 
Fig. 5. Large biotite (Bt) and chloritized biotite (Ch) flakes and kaolinite (Ko) plates among fine flakes of high-illitic illite/smectite and illite (SEM/EDX) • Duże blaszki biotytu zubożonego w Fe, schlorytyzowanego biotytu i płytki kaolinitu wśród drobnych blaszek wysokoillitowego illitu/smektytu i illitu. (SEM/EDX)

above the sediments but pore waters impoverished in oxygen. Organic matter contained in them is of continental/marine origin with predominance of the latter. During late diagenesis, documented by the composition of clay minerals and microstructural features of the shales in question, organic matter has gained considerable thermal maturity. The occurrence of high-illitic illite/smectite, Fe-impoverished and chloritized biotite and the microstructures, characterizing by one-directional orientation of clay minerals and rotation of often chloritized mica flakes the result of post-sedimentary processes under conditions of late diagenesis. $\square$

Acknowledgements: This work was partially financial supported by AGH University of Science and Technology grant: 11.11.140.158.
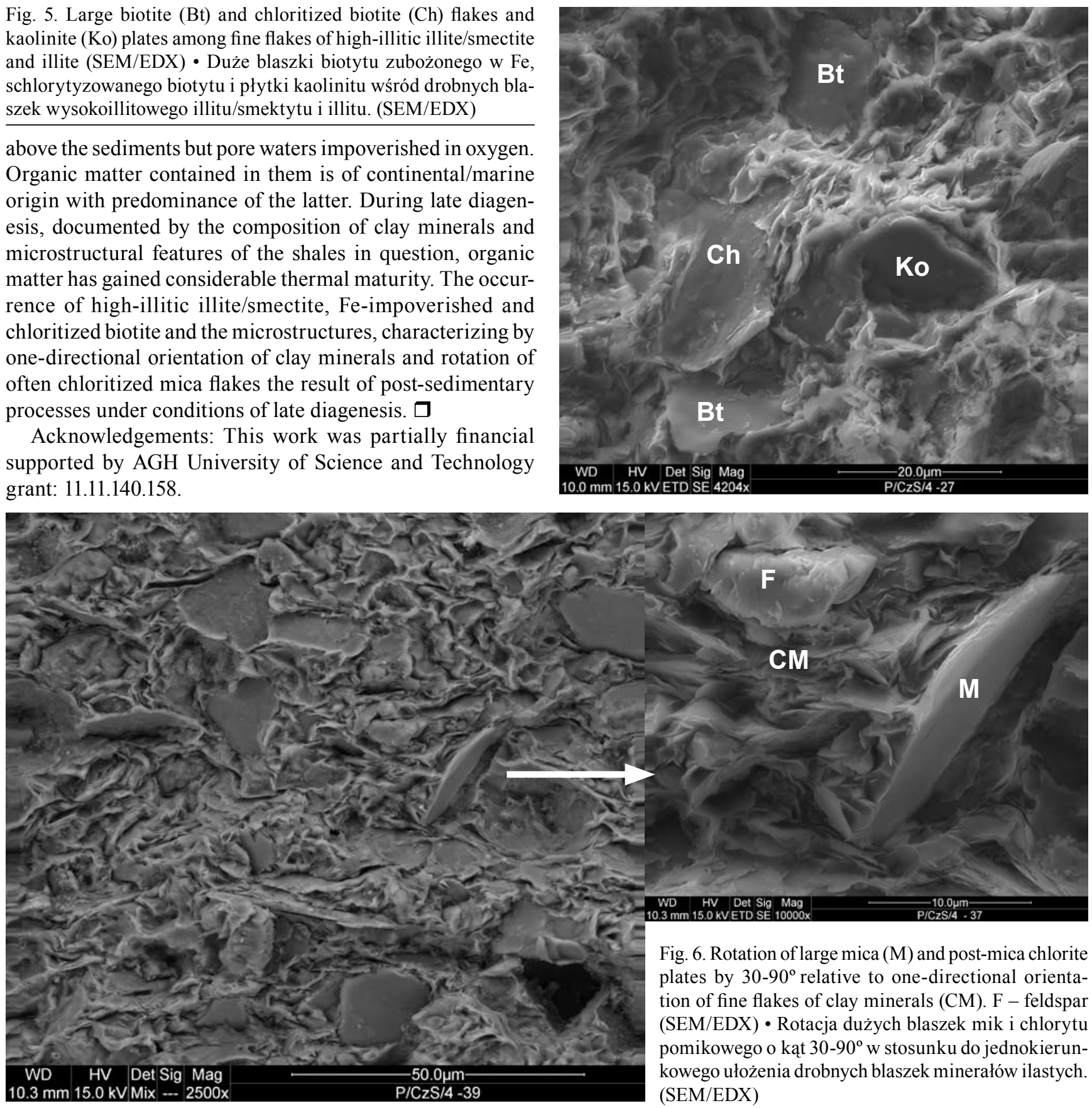

Streszczenie

\section{Środkowojurajskie czarne lupki (formacja lupków ze Skrzypnego)}

- znaczenie paleośrodowiskowe jednych z najstarszych osadów pienińskiego pasa skałkowego

\section{Katarzyna Górniak, Krzysztof Bahranowski, Adam Gawel, Leszek Marynowski \& Tadeusz Szydlak}

Ciemne wczesnojurajskie facje margliste (typu Fleckenmergiel) budzą szczególne zainteresowanie badaczy, ponieważ w utworach tych zapisane są początkowe fazy rozwoju basenu pienińskiego (Birkenmajer, 1986, Krobicki \& Golonka, 2008 a i literatura tam cytowana). W polskiej części Pienińskiego Pasa Skałkowego, jednymi z najstarszych skał należących do tych facji są czarne łupki sferosyderytowe z małżami Bositra (formacja lupków ze Skrzypnego) wieku późny aalen-wczesny bajos (Krobicki \& Golonka, 2008a, Fig. 7). Formacja łupków ze Skrzypnego jest opisywana jako seria skał ilastych o barwie czarnej i czarnozielonej z konkrecjami syderytowymi w których spotyka się amonity. Miąższość formacji określa się na około $5 \mathrm{~m}$. Te interesujące utwory odsłaniają się w górnej części wąwozu Homole, na przełęczy pod Czajakową Skałą (Krobicki \& Golonka, 2008a, Fig. 12D). 


\section{Przełęcz pod Czajakową Skałą - odsłonięcie utworów formacji łupków ze Skrzypnego}

Formacja łupków ze Skrzypnego odsłaniająca się na przełęczy pod Czajakową Skałą należy do sukcesji niedzickiej. Utwory sukcesji niedzickiej w wąwozie Homole występują w formie płatu kontaktującego z podłożem tektonicznie. Płat ten tworzy fałd obalony, silnie wtórnie sfałdowany nazywany Czajakową Skałą. Formacja łupków ze Skrzypnego występuje w spągu sukcesji niedzickiej. Fragment struktury fałdu Czajakowej Skały został przemieszczony po warstwie tych łupków stanowiących powierzchnię poślizgu i obecnie widoczne są one w osuwisku znajdującym się w górnej części wąwozu Homole (Krobicki \& Golonka, 2008a, Fot. 12D). Utwory formacji łupków ze Skrzypnego w tym niewielkim odsłonięciu wykształcone są jako drobnołupiące się, ciemnoszarooliwkowe łupki z blaszkami miki o wielkości do $0.5 \mathrm{~mm}$ i z brązowymi konkrecjami syderytowymi. Łupki są miękkie, słabo wapniste, bezpiaszczyste. Wielkość sferosyderytów nie przekracza kilkunastu centymetrów. Są one twarde, pryskliwe, ze szczelinami zabliźnionymi kalcytem. Jak wynika ze szczegółowych badań W. Narębskiego (Birkenmajer \& Narębski, 1957) konkrecje te są zbudowane z syderoplezytu (Mg-syderyt) ze znacząca domieszką kalcytu. Skład chemiczny konkrecji wskazuje, że powstały one w czasie wczesnej diagenezy w słabo redukcyjnych warunkach facji syderytowej (Birkenmajer \& Narębski, 1957). Bochenkowaty kształt również wskazuje na ich wczesnodiagenetyczną genezę (Seilacher, 2001).

Ciemna barwa osadów rozpoczynających sedymentację w basenie pienińskim sugeruje, że są to utwory deponowane w warunkach niedoboru tlenu, umożliwiających zachowanie w osadzie substancji organicznej. Z takimi niedotlenowymi środowiskami wiąże się powstanie skał macierzystych dla złóż ropy naftowej i gazu. Demaison i Moore (1980) uważają środowisko za niedotlenione jeśli w jednym litrze wody rozpuszczone jest mniej niż 0.5 mililitra tlenu. Takie warunki tworzą się wówczas kiedy zapotrzebowanie na tlen wodzie jest większe niż jego dostawa. Zapotrzebowanie na tlen zależy od produktywności wód powierzchniowych, a dostawa tlenu do osadu od cyrkulacji prądów. Uważa się, że warunki zubożone w tlen szczególnie powszechnie panowały w późnej jurze i wczesnej kredzie z powodu globalnego ocieplenia klimatu i podniesienia poziomu wód w oceanach. Skały macierzyste największych znanych złóż ropy i gazu są tego wieku. Warunki anoksyczne mogą tworzyć się też lokalnie. Przez analogię do współczesnego środowiska oceanicznego (strefa skłonu kontynentalnego Oceanu Indyjskiego) uważa się, że osady niedotlenione gromadzą się w obszarach, w których prądy niosące wody zubożone w tlen (nie więcej niż $0.5 \mathrm{ml}$ tlenu/litr wody) wkraczają na skłon kontynentalny. Model ten odpowiada warunkom panującym w basenie pienińskim w środkowej jurze. Ciemne facje margliste tego wieku pojawiają się wśród utworów sukcesji niedzickiej deponowanej na skraju szelfu kontynentalnego i sukcesji czorsztyńskiej gromadzonej na skłonie grzbietu czorsztyńskiego. Pierwsze z wymienionych, jak wspomniano powyżej, są jednymi z najstarszych utworów budujących fałd Czajakowej Skały i widoczne są w najwyższej części wąwozu Homole, drugie odsłaniają się w potoku Krupianka (Krobicki \& Golon- ka, 2008a, Fot. 14A i literatura tam cytowana). Warunki batymetryczne dla facji Fleckemergiel podane przez Tyszkę (2001) w oparciu o badania mikroskamieniałości odpowiadają strefie zewnętrznego szelfu i skłonu.

Serie ciemnych skał ilastych gromadzące się w środowiskach zubożonych w tlen zwykle pozornie są monotonne. Powiązanie badań sedymentologicznych, paleontologicznych i geochemicznych przeprowadzonych dla utworów dolnojurajskich (Yorkshire, Wielka Brytania) pozwoliło zdefiniować trzy facje występujące w basenach zdominowanych przez wody generalnie niedotlenione. Są to facje: łupków normalnych (normal shale), łupków słabo bitumicznych (restricted shale) i łupków bitumicznych (bituminous shale) (Morris 1979). Przyczyną tego zróżnicowania facjalnego jest cyklicznie zmieniające się położenia granicy między strefą natlenioną i zubożoną w tlen w słupie wody na osadem.

Cechy litologiczne utworów formacji łupków ze Skrzypnego sukcesji niedzickiej odsłaniające się na przełęczy pod Czajakowa Skałą reprezentują fację łupków normalnych. Wynika to z porównania ich cech z cechami osadów podanymi przez Morrisa (1979) dla poszczególnych facji. Środowisko w jakim powstaje facja łupków normalnych to: położenie granicy między warunkami utleniającymi i redukcyjnymi w obrębie osadu i natlenionych wód nad osadem. W takim środowisku możliwy jest rozwój epifauny i infauny oraz nagromadzenie jej w osadzie (Fig. 1). Jednocześnie są to warunki geochemiczne w których mogą tworzyć się konkrecje syderytowe (Birkenmajer \& Narębski, 1957; Potter et al., 2005).

Badane utwory formacji łupków ze Skrzypnego zawierają około $1 \%$ całkowitego węgla organicznego (TOC) oraz śladowe ilości siarki. Biorąc pod uwage przypowierzchniowe zwietrzenie badanego materiału, pierwotna ilość TOC była zapewne wyższa, co wskazuje na sedymentację w warunkach zubożonych w tlen. Wskaźnikiem warunków redoks panujących w środowisku sedymentacji skał zasobnych w substancje organiczną są biomarkery. Biomarkery pozwalają określić również pochodzenie substancji organicznej nagromadzonej w osadach. Biomarkery to „molekularne skamieniałości” (molecular fossils) czyli fragmenty substancji organicznej, które zachowują budowę wewnętrzna wyjściowych biomolekuł. Stopień natlenienia kolumny wody podczas sedymentacji łupków ze Skrzypnego określa stosunek pristanu do fitanu czyli izoprenoidów obecnych w badanych próbkach. Wartość tego stosunku wynosi 1,8, co sugeruje raczej tlenowe warunki sedymentacji substancji organicznej, przy czym nie są to dane jednoznaczne i należy je traktować jako wyjściowe do dalszych badań. Zatem, stosunkowo wysoka zawartość węgla organicznego w badanych skałach oraz raczej tlenowe warunki sedymentacji, sugerują występowanie warunków suboksycznych do anoksycznych już w osadzie na wczesnym etapie diagenezy (Fig. 1). Z powodu stosunkowo wysokiej dojrzałości termicznej materii organicznej oraz jej częściowego utlenienia w próbkach nie stwierdzono terpenoidów i steroidów. Przewaga $n$-alkanów krótkołańcuchowych, $\mathrm{z}$ maksimum przy $n-\mathrm{C}_{16}$ wskazuje na raczej morski charakter materii organicznej. Jednak w zakresie $n$-alkanów długołańcuchowych uwidacznia się lekka przewaga $n$-alkanów nieparzysto węglowych $\left(n-\mathrm{C}_{27}, n-\mathrm{C}_{29}, n-\mathrm{C}_{31}\right)$, co z kolei wskazuje na składnik lądowej materii organicznej. $\mathrm{Z}$ danych tych 
wynika, że materia organiczna badanych skał jest mieszanego, lądowo/morskiego pochodzenia z wyraźną przewaga morskiej substancji organicznej.

Złożona historia geologiczna Pienińskiego Pasa Skałkowego powoduje, że nie tylko substancja organiczna ale i pierwotne cechy utworów formacji łupków ze Skrzypnego są w znacznym stopniu zmienione przez procesy diagenezy i deformacje tektoniczne. Utwory formacji łupków ze Skrzypnego sukcesji niedzickiej odsłaniające się na przełęczy pod Czajakową Skałą zbudowane są głównie z minerałów ilastych i mik (około 77\% wag.). Minerały ilaste są reprezentowane przez wysokoillitowy illit/smektyt, illit, chloryt i kaolinit. Ponadto $\mathrm{w}$ badanych skałach występuje kwarc (około 20\% wag.), śladowo skalenie oraz kalcyt (około 3\% wag.) (Fig. 2).

Skutkiem procesu kompakcji jest jednokierunkowa orientacja blaszek minerałów ilastych (illit/smektyt, illit) oblekających drobne ziarna kwarcu oraz nieliczne skalenie i bioklasty (Fig. 3). Ziarna kwarcu (Fig. 4) i skaleni są bardzo drobne. Mają wielkość nie przekraczającą kilkunastu mikrometrów. Bioklasty są silnie zniszczone, z licznymi kawernami z rozpuszczania (Fig. 3). Duże blaszki miki, często schlorytyzowanej oraz płytki kaolinitu o wielkości osiągającej od kilkunastu do kilkudziesięciu mikrometrów (Fig. 5) wykazują rotację o kąt od 30 do $90^{\circ} \mathrm{W}$ stosunku do jednokierunkowego położenia drobnych blaszek minerałów ilastych (Fig. 6).
Mikrostruktura, skład minerałów ilastych oraz stan zachowania substancji organicznej opisane powyżej wskazują, zgodnie z kryteriami Weavera (1989), że badane utwory formacji łupków ze Skrzypnego ulegały procesom charakterystycznym dla późnego etapu diagenezy.

Utwory formacji łupków ze Skrzypnego z omawianego odsłonięcia nie były jak dotąd przedmiotem tak szczegółowych badań. Swoją historię geologiczną ujawniają po przeprowadzeniu badań rentgenograficznych, geochemicznych i przy użyciu mikroskopu elektronowego (SEM/EDX). Z badań tych wynika, że sedymentacja utworów formacji łupków ze Skrzypnego sukcesji niedzickiej przebiegała w warunkach natlenionych wód nad osadem i zubożonych w tlen wód porowych. Substancja organiczna w nich zawarta jest pochodzenia lądowo/morskiego z wyraźną przewagą ostatniej z wymienionych. W warunkach później diagenezy zamanifestowanej w składzie minerałów ilastych i w cechach mikrostrukturalnych badanych utworów substancja organiczna osiągnęła znaczną dojrzałość termiczną. Występowanie wysokoillitowego illitu/smektytu, zubożonego w Fe i schlorytyzowanego biotytu oraz mikrostruktur charakteryzujących się jednokierunkowym ułożeniem blaszek minerałów ilastych i rotacją blaszek mik, często schlorytzowanych, jest skutkiem procesów posedymentacyjnych odpowiadających warunkom późnej diagenezy.

Podziękowania: Praca była częściowo finansowana przez Akademię Górniczo-Hutniczą, umowa nr 11.11.140.158.

\section{References (Literatura)}

Birkenmajer, K., 1986. Stages of structural evolution of the Pieniny Klippen Belt, Carpathians. Studia Geologica Polonica, 88: 7-32.

Birkenmajer, K. \& Narębski, W., 1958. Konkrecje węglanowe łupków aalenu pienińskiego pasa skałkowego Polski. Rocznik Polskiego Towarzystwa Geologicznego, XXVII, 51-74.

Demaison, G. J. \& Moore, G.T. 1980. Anoxic Environments and oil source bed genesis. The American Association of Petroleum Geologists Bulletin, 64, 8: 1179-1209.

Krobicki, M. \& Golonka, J., 2008. Geological history of the Pieniny Klippen Belt and Middle Jurassic black shales as one of the oldest deposits of this region - stratigraphical position and palaeoenvironmental significance. Geoturystyka (ten tom).

Morris, K. A., 1979. A classifcation of Jurassic marine shale sequence: an example from the Toarcin (Lower Jurassic) of Great Britain. Paleogeography, Paleoclimatology, paleoecology, v.26:117-120.
Potter, P. E., Maynard, J.B. \& Depetris, P.J., 2005. Mud and Mudstones. Springer 297pp.

Moore, D.M. \& Reynolds, R.C., Jr. 1997. X-ray diffraction and the identification and analysis of Clay Minerals.Oxford University Press. New York, 378.

Seilacher, A., 2001. Concretion morphologies reflecting diagenetic and epigenetic pathways. Sedimentary Geology, 143, 41-57.

Tyszka, J., 2001. Microfossil assambladges as bathymetic indicators of the Toarcian/Aalenian "Fleckenmergiel" - facies in the Carpathian Pieniny Klippen Belt. Geologica Carpathica, 52: 147-158.

Weaver, C.E., 1989. Clays, muds and shales. Development in Sedimentology 44. Elsevier, Amsterdam, 819pp. 